\title{
An Analysis of Lexical and Syntactical Errors in English Abstract Made by Students of the Accounting Department Polmed
}

\author{
Nuraini $^{1}$, Ridwan Hanafiah ${ }^{2}$, Masdiana Lubis ${ }^{3}$ \\ 1,2,3University of Sumatera Utara
}

Email corresponding author: nuraini@students.usu.ac.id, rh56usu@gmail.com², masdianalbs26@gmail.com ${ }^{3}$

\begin{abstract}
The main purpose of the study is to find out the kinds of lexical and syntactical errors in writing the student's paper of English Abstract. The data collecting technique used the field research method from 25 student's papers of English abstract of Accounting Department Politeknik Negeri Medan. The method used in the research is a qualitative approach. The findings of the research revealed that there were so many errors found in the student's papers of English abstract. There were two kinds of lexical errors relate to Semantic Error in Lexis found in the student's papers of English abstract which are Confusion of Sense Relations and Collocational Errors. The number of errors in Confusion of Sense was 20 errors with percentage $62.50 \%$ while the collocational errors were also found as many as 12 errors that constituted $37,50 \%$ of the total errors collected in the data analysis process. The errors in the syntactical level are also found in the student's paper of English abstract based on surface structure taxonomy. There were five kinds of errors found in the analysis process. The most frequent errors made by students are misformation $62(40,79 \%)$ of error followed by omission error reach 54 (35,53\%) of errors. The addition errors reach $22(14,47 \%)$ of error. then, misordering errors are found 13 (8,55\%) of errors. finally, the blend is only found $1(0,66 \%)$ of errors in student's papers of English abstract in Accounting Department Politeknik Negeri Medan.
\end{abstract}

Keywords: Lexical, syntactical, error, semantics, taxonomy.

\section{INTRODUCTION}

In academic writing, students are required to make the sentences that are correct grammatically. It is because academic writing serves accurate information and data that can be verified. One type of academic writing is abstract.

The errors of lexical and syntactical in the abstract are most likely for the reader to get a different interpretation which is different from the context of the research. Therefore, the case is a very interesting problem to analyze. In this case, the kinds of 
lexical and syntactical errors in writing the student's paper of English Abstract of Accounting Department will be analyzed.

The several kinds of errors identified based on errors classification by (James, 1998) who has classified grammar errors into five main groups: morphology errors, syntax errors, discourse errors, pragmatic errors, and receptive errors. In this case, the research focuses on Lexical and Syntactical Errors to analyze the data. so, the researcher used surface structure taxonomy from (Dulay, Burt, 1982), and (James, 2013) and semantic error in lexis from (James, 2013).

Some research on error analysis in the second language of learning has been done by several people. They are (Gayo \& Widodo, 2018), (Hafiz, 2018), (Gedion \& Peter, 2016), (Hafiz, 2018), (Alamin \& Ahmed, 2012) and (Saud, 2018)

Based on the similar researches above, this study discusses an analysis of lexical and syntactical errors in English Abstract Made by Students of the Accounting Department Politeknik Negeri Medan. The research used the English abstract of Diploma 3 postgraduate students to be studied as an object of the research. The researcher assumed that the students in the postgraduate period more comprehend in English subjects than the first semester because they have passed all of the English subjects in the Accounting Department.

The differences in the study with other research are found in the theory used to analyze the lexical and syntactical errors. The theory of the previous study refers to (Dulay, Burt, 1982) theory. in the study, the researcher combined the theory between (Dulay, Burt, 1982) and (James, 2013) theory to analyze data whereas one the differences of theory exist in the types of Surface Structure Taxonomy and semantics error in lexis which are the focus of the study.

\section{LITERATURE REVIEW}

\section{Error Analysis}

Dulay \& Burt (1982) mention the definition of Error as the imperfect part that owned by the learner in their speech or writing, and it made the part in conversation and composition depart from some selected norm of mature language performance (Richard, 2010) regard errors as linguistic forms, which in the same context a native speaker would not produce. They further emphasize that errors are deviations from the norm. This requires the speaker to switch to communication strategies such as simplification, avoidance, code-switching, and paraphrasing.

(Brown, 2006) argues that error analysis (EA) has great value in classroom research. The systematic analysis of errors made by the second language learners makes determining areas that need strengthening in teaching possible (Corder, 1974). Error Analysis has been revealed by (James, 1998) as "the process of determining the events, nature, causes, and consequences of non-functioning language. 
One of the most important studies conducted in the field of Error Analysis was done by (James, 2013) Error is likewise unique to humans, who are not only sapiens and loquens but also homo errands.

\section{Types of error}

The several kinds of errors identified based on errors classification by (James, 1998) who has classified grammar errors into five main groups: morphology errors, syntax errors, discourse errors, pragmatic errors, and receptive errors. In this case, the research focuses on the lexical and syntactical errors to analyze the data so the researcher used surface structure taxonomy from (Dulay, Burt, 1982) and (James, 2013) and semantic error in lexis from (James, 2013).

\section{The surface structure taxonomy.}

(James, 2013) concluded that viable taxonomy can operate with four of their categories plus a fifth (blends) of his own. They are omission which reflected by the lack of an item that have to appear in a well-formed utterance of the target language, addition reflected by the presence of an item that must not appear in a well-formed utterance of the target language, misformation described as the use of the error form of a morpheme, misordering indicated by the incorrect placement of certain morphemes and blend occurs when two or more morphemes that have the same function appear in a sentence.

\section{Semantic errors in lexis}

(Llach, 2011) defines lexical error as a deviation in the form and/or meaning of a word in the target language. According to (Ellis, 1994) states that Lexical errors are the most frequently occurring category of errors in written English. (James, 2013) classified lexical errors into two categorizes included Formal errors of lexis and Semantic errors in lexis. However, the study of the research is limited by semantic errors in lexis. There are two types of semantic errors in lexis which are the confusion of sense relations and collocational error.

\section{METHODOLOGY}

The method used in the research is a qualitative approach. (Miles and Hubermen, 1994) stated that the Qualitative research is organize through an intense and/or prolonged contact with a 'field' or life situation. Besides, (Flick, 2009) revealed that Qualitative research is the specific relevance to the social relations studey, due to the fact of the pluralization of life-worlds.

The Subject of this study is the Accounting Department Students of Politeknik Negeri Medan. The primary data are all the words, phrases and, clauses in the student's paper of English abstract in the 2019 Period. There are 244 English Abstracts 
in the Accounting Department, Politeknik Negeri Medan can be analyzed. (Roscoe, 1975) provides the 'rule of thumb' for determining sample size; For sample experiment research with tight experimental controls (matched pair, etc.), successful research is possible with a small sample size as 10 to 20 in size. Therefore, based on the calculation above, the sampling size that will be used in this research is $10 \%$ of participant that is 25 respondents randomly.

The technique of data collecting is the first main step in the research. In this data collecting technique, the researcher used the field research method. It was data collecting directly to the field by getting the abstract from the institute. Collecting data can be done in any setting, any sources, and any ways.

In qualitative research, collecting the data mostly is done in participant depth interviews and documentation. (Sugiyono, 2008) stated that the fundamental method relied on by qualitative researchers for gathering information is participation in the setting, direct observation, in-depth interviewing, and documentation review. In this research, the researcher uses documentation to collect the data.

\section{FINDING AND DISCUSSION}

\section{Lexical Error}

The result of the study is taken from the student's paper of English abstract of Diploma 3 postgraduate students in Accounting Department Polmed as an object of the research. Based on the analysis of the research, the errors are found in lexical levels focused on semantic error in lexis. The data are presented clearly on the chart below:

chart 1. research finding of semantic error in lexis

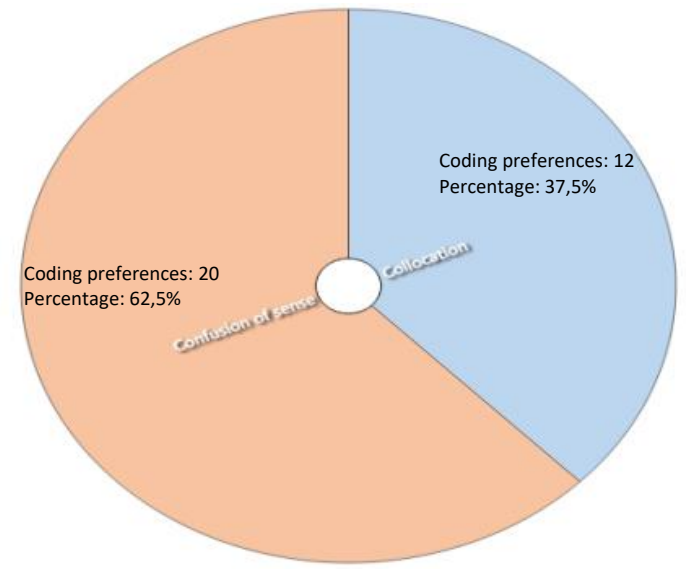

The chart describe the kinds of lexical based on (James, 2013) theory. There were two kinds of lexical errors relate to semantic error in lexis found in the student's papers of English abstract which are confusion of sense relations and collocational errors. The number of errors in confusion of sense were 20 errors which divided into four types of errors such as general term for specific one reach 14 errors with percentage $43,75 \%$, 
overtly specific term, inappropriate co-hyponymy which no found an error and nearsynonyms reach 6 of errors with percentage $18,75 \%$. The collocational errors were also found as many as 12 errors that constituted $37,5 \%$ of the total errors collected in the data analysis process.

\section{Confusion of sense relations}

(Hemchua, S., \& Schmitt, 2006) stated that the meaning of vocabulary generally necessitates concepts and their relations in the lexical field (for instance, the words man and boy belong to the lexical field of 'gender'). The analysis revealed that there were several errors in the confusion of sense relations found in the student's paper of English abstract which was the most frequent category of lexical semantic errors. it shows that the student is still confused by the use of the specific term based on the topic. the errors made by the student are influenced by inter-lingual interference which the students made the errors in the target language by the effect of their mother tongue. The following examples are the errors made by the student in the confusion of sense relation such as:

1. This research aims to determine the application of asset accounting in Regional office VI of the *State personnel Agency (BKN). The student translates Badan Kepegawaian Daerah literally. The student has to change from general term to specific one. The institution of BKN has the specific term in English. The suggestion for the error is National Civil Service Agency.

2. proof of the state income (bukti penerimaan negara)

The word proof is inappropriate put in the phrase. The student's paper discusses taxation. It means that the phare has to use the specific term in the taxation term. The word proof must be changed into evidence. Another error is also found in the phrase. The phrase penerimaan negara has also the specific term which is government revenues. The suggestion for the correct phrase is government revenues evidence.

The following examples are the errors made by the student in General term for specific one

1. ${ }^{*}$ Minister of State (Menteri BUMN) (the minister for state own enterprises).

2. PT. Jaya Beton Indonesia complies with the taxation *law arranged (undangundang) (regulation of law) No.36/2008 concerning Income Taxes State personnel Agency (BKN) Medan with the general applicable *rules of abuse (peraturan perundang-undangan) (rules and regulation) relating to the accounting of fixed asset.

\section{Collocational errors}

The students also made errors in collocation. The errors have a negative impact on the academic writing of student's papers of English abstract. the errors are mostly 
influenced by the translation technique. The following examples are mostly caused by intralingual interference rather than inter-lingual interference. The student confuse are wrong in the combination with preposition and pronoun as follows:

1. There is often a double position between the goods storage function *with the cashier. The word between is always correlate with and. The word with has to replace with the word and. the correct sentence is There is often a double position between the goods storage function and the cashier

2. From the result of the analysis it can be concluded. the preposition from is not suitable in the sentence. Preposition from are used to show when something starts example: We are open from 7 to 8 every day, used to show the material that something is made of, and used to show someone's position or point of view. It means the word form must be replaced with based on.

\section{Syntactical errors}

Chart 2. research finding surface structure taxonomy

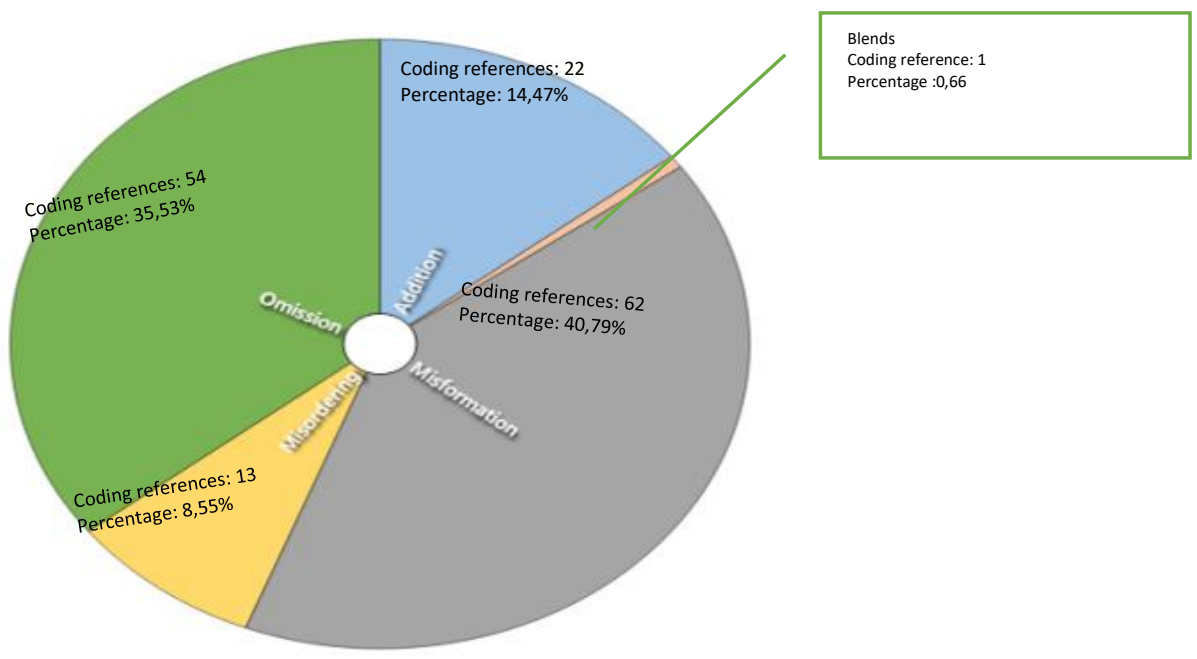

Some of the errors are delicate to categorize unambiguously, however the error in word meaning may be caused by ignorance of just one word, but its impacts are sometimes global: which is the entire sentence can be affected in unexpected ways (Sanders, 1987). The analysis revealed that so many errors made by the students in the paper of English abstract. the study focused on surface structure taxonomy. The taxonomy works on mechanisms in which the surface forms are modified in erroneous utterances. The common errors in surface structure taxonomy level made by the students show in the chart below:

The errors in the syntactical level are found in the student's paper of English abstract based on surface structure taxonomy. There were five kinds of errors found in the analysis process. The most frequent errors made by students are misformation $62(40,79 \%)$ of error followed by omission error reach $54(35,53 \%)$ of errors. The 
addition errors reach $22(14,47 \%)$ of error. then, misordering errors are found 13 $(8,55 \%)$ of errors. finally, the blend is only found $1(0,66 \%)$ of errors in student's papers of English abstract in Accounting Department Politeknik Negeri Medan.

\section{Omission}

There are some errors made by students in writing the paper. The omission error occurs when there is a word or phrase to be missing in a sentence or clause such that article "a", "an" or "the". The English language uses articles to identify nouns. Articles act much like adjectives. Articles establish whether a noun is specific or general, singular or plural. An article appears before the noun it accompanies for the example He was born in the 1982. The following examples are the errors occurred caused by the omission of article as follow:

1. The data analysis used in this study was *descriptive (the descriptive) method.

2. unexpected results ${ }^{*}$ which taken from the Revenue and Expenditure Budget Regional (the past participle verb taken has been used without an auxiliary verb. The suggest sentence is unexpected results which are taken from the Revenue and Expenditure Budget Regional.

\section{Addition}

Addition is an error characterized by the presence of an item that must not appear in a well-formed utterance of the target language. (Dulay, Burt, 1982) suggest is the 'result of all-too-faithful use of certain rules' (1982: 156). The students made the addition error in writing the paper. The following clause are the addition error made by the students as follow:

1. The results of the research shows that...

The singular verb shows doesn't appear to agree with the plural subject result. The sugest for the clause is consider to change the verb form for subject-verb agreement. The correct clause is (The results of the research show that...)

2. Data collection techniques conducted in this study is documentation.

the phrase of techniques is doesn't agree with the number of object documentation. The suggest clause is (Data collection technique conducted in this study is documentation)

\section{Misformation}

Dulay, Burt and Krashen defined misformation as the use of the wrong form of a or morpheme. Misformation is the most common errors found in writing student's papers. The analysis revealed that one of the error is incorrect in subject-verb agreement which involved the wrong used of 'to be', preposition form, and word form as the examples below:

1. Data collection is (are) done through interviews and documentation. 
The clause needed a plural noun phrase because after the verb phrase, the conjunction And showed more than one speech function. Therefore, the student should change it into a plural form of the noun for the proper sentence (Data collections). In addition, the use of article is necessary.

2. Data processing method used are (is) descriptive

The subject (data processing) method is singular while the verb is plural. The subject and verb must agree in number: it must be singular, or plural.

\section{Misordering}

Misordering is indicated by the incorrect placement of certain morphemes. Misordering happened since the learners placed or ordered a few words incorrectly in their sentences. As described by (Dulay, Burt, 1982). The sentences below are the errors made by the students as follow:

1. This research uses data method collection (data collection method)

2. in the organizational structure the number of resources (the number of resources in the organizational structure)

\section{Blends}

Blends occurs when two or more morphemes that have the same function appear in a sentence for example: *according to Erica's opinion The most possible reason to this blends error is that the student is not sure which one of the form is used (James, 1998), so he/she put both "according" and "opinion" in the sentence. Blends was in the last rank in the research. It means that the students infrequently committed blends error in their writing composition. Based on the result of the research there is only $1(1,35 \%)$ error made by the students. The example below shows the case:

1. Based on the findings of the result of this study the meaning of those two is just the same, so it is unnecessary to write down

findings in the sentence. Below is the correction to the sentence:

(Based on the result of the study)

\section{CONCLUSION}

The findings of the study show that there are so many errors found in the student's papers of English abstract of Accounting Department Politeknik Negeri Medan. Writing in English form, the students tend to make all error types in terms either or both of semantic error in lexis covering Confusion of sense relations error and collocational error, and surface strategy taxonomy covering omission, addition, misformation, misordering, and blends. In terms of surface structure taxonomy, the most frequently commit misformations and least often make blends; while in terms of semantic error in lexis, they more dominantly commit Confusion of sense relations error than collocational errors in their writings. In general, the students frequently 
make errors in their paper dealing with the use of general term for specific one and subject-verb agreement.

\section{References}

Alamin, A., \& Ahmed, S. (2012). Syntactical and punctuation errors: An analysis of technical writing of University Students science college, Taif University, KSA. English Language Teaching, 5(5), 2-8. https://doi.org/10.5539/elt.v5n5p2

Azevedo, M. M., \& Corder, S. P. (1983). Error Analysis and Interlanguage. The Modern Language Journal, 67(1), 85. https://doi.org/10.2307/326720

Brown, H. D. (2006). Principles of Language Learning and Teaching (fifth edit; D. Belfiore, ed.). Retrieved from http://angol.uni-miskolc.hu/wpcontent/media/2016/10/Principles_of_language_learning.pdf

Corder, S. P. (1974). Error Analysis, Interlanguage and Second Language Acquisition. https://doi.org/10.1017/S0261444800002822

Dulay, Burt, \& K. (1982). Language Two. New York, Oxport University Press.

Ellis, R. (1994). The study of Second Language Acquisition. Oxford: Oxford University Press.

Flick, uwe. (2009). An Introduction to Qualitative Research (Fourth edi). London: SAGE Publication, Ltd.

Gayo, H., \& Widodo, P. (2018). An analysis of morphological and syntactical errors on the English writing of junior high school Indonesian students. International Journal of Learning, Teaching and Educational Research, 17(4), 58-70. https://doi.org/10.26803/ijlter.17.4.4

Gedion, A., \& Peter, J. C. (2016). A Syntactic Errors Analysis in the Malaysian ESL Learners' Written Composition. Journal of Applied Linguistics and Language Research, 3(6), 96-104.

Hafiz, M. S. (2018). Analysis of Syntactic Errors in English Writing : A Case Study of Jazan University Preparatory Year Students. 9(11), 113-120.

Hemchua, S., \& Schmitt, N. (2006). An Analysis of Lexical Errors in the English Compositions of Thai Learners.

James, C. (1998). Errors in Language Learning and Use. University of California: Longman.

James, C. (2013). Errors in Language Learning and Use (P. C. N. CANDLIN, ed.). Retrieved from file:///F:/New folder (2)/(Applied Linguistics and Language Study) Carl James - Errors in Language Learning and Use_Exploring Error Analysis-Routledge (2013).pdf

Llach. (2011). Lexical Errors and Accuracy in Foreign Language Writing. Bristol: Multilingual Matters.

Miles and Hubermen. (1994). Qualitative data analyis (Second Edi). California: SAGE Publication, Inc. 
Richard, jack R. (2010). LANGUAGE TEACHING AND APPLIED LINGUISTICS (fourth edi). Great Britain.

Roscoe, J. . (1975). Fundamentals Research Statistics for Behavioural Sciences. (2nd.). in Hill, R. (1998). "What SampleSize is 'Enough' in Internet Survey Research"? Interpersonal Computing and Technology: An electronic Journal for the 21st Century. Available at: http://www.emoderators.com/ipct-j/1998/n3-4/hill.hmtl.

Sanders, R. (1987). Error Analysis In Purely Syntactic Parsing Of Free Input The Example Of German. CALICO Journal, Volume 9(Number 1), 75.

Saud, W. I. (2018). Lexical Errors of Third Year Undergraduate Students. English Language Teaching, 11(11), 161. https://doi.org/10.5539/elt.v11n11p161

Sugiyono. (2008). Metode penelitian pendidikan:(pendekatan kuantitatif, kualitatif dan R \& D. Bandung: Alfabeta. 